\title{
Peningkatan Kepercayaan Diri Anak Usia Dini melalui Kegiatan Jurnal Pagi
}

\author{
Kurniasih $^{\varpi_{1}}$, Asep Supena ${ }^{2}$, Yuliani Nurani ${ }^{3}$ \\ Pendidikan Guru Pendidikan Anak Usia Dini, Universitas Negeri Jakarta \\ DOI: $10.31004 /$ obsesi.v5i2.1109
}

\begin{abstract}
Abstrak
Penelitian dilakukan untuk mengetahui implementasi kegiatan jurnal pagi dalam meningkatkan rasa percaya diri anak kelompok B di Paud Al-Istiqlaliyyah, Kecamatan Benda, Kota Tangerang. Menggunakan Penelitian Tindakan model Kemmis \& Mctaggart. 12 anak menjadi subyek penelitian. Data dianalisis secara kualitatif dan kuantitatif. Analisis kuantitatif menggunakan statistik deskriptif dengan membandingkan hasil siklus I dan II. Analisis data kualitatif dengan menganalisis data hasil catatan lapangan dan wawancara penelitian dengan reduksi data, display data dan verifikasi data. Hasil persentase analisis data peningkatan percaya diri anak pada siklus I 62,85\% menunjukkan rata-rata tingkat capaian perkembangan anak pada aspek padangan positif terhadap diri sendiri, keberanian, dan optimisme anak mengalami peningkatan dibandingkan hasil pra-siklus. Hasil analisis siklus II $82.52 \%$ menunjukkan rata-rata tingkat capaian perkembangan dari tiga aspek kepercayaan diri anak telah mencapai kriteria keberhasilan yang ditentukan (75\%). Dengan demikian kegiatan jurnal pagi dapat meningkatkan kepercayaan diri anak. Keterbatasan penelitian adalah proses mendokumentasikan kejadian penting belum maksimal.
\end{abstract}

Kata Kunci: kepercayaan diri anak; jurnal pagi; pendidikan anak usia dini

\begin{abstract}
This study aims to determine implementation of morning journal activities in improve the selfconfidence of group B children in Paud Al-Istiqlaliyah, Benda District, Tangerang City. Using the Kemmis \& Mctaggart model of action research. 12 children were the research subjects. Data were analyzed qualitatively and quantitatively. Quantitative analysis uses descriptive statistics by comparing the results of cycles I and II. Qualitative data analysis by analyzing data from field notes and research interviews with data reduction, data display and data verification. The results of the percentage of data analysis on the improvement of children's self-confidence in the first cycle of $62.85 \%$ showed that the average level of children's development achievement in the aspects of positive self-view, brave, and optimism of children improved compared to the pre-cycle results. The results of the second cycle analysis of $82.52 \%$ showed that the average level of developmental achievement of the three aspects of children's self-confidence had reached the specified success criteria $(75 \%)$. Thus morning journal activities can increas children's confidence. The limitation of research is that the process of documenting important events has not been maximized.
\end{abstract}

Keywords: child's self-confidence; morning jurnal; early childhood education.

Copyright (c) 2021 Kurniasih, Asep Supena, Yuliani Nurani

$\triangle$ Corresponding author:

Email Address : kuniasihnajwa@gmail.com (Benda, Tanggerang)

Received 28 January 2021, Accepted 1 March 2021, Published 14 March 2021 


\section{PENDAHULUAN}

Kepercayaan diri anak adalah suatu sikap positif memandang kemampuan diri, tenang, merasa mampu menyesuaikan diri dan mengaktualisasikan diri (Nurmaniah \& Damayanti, 2018). Menurut teori sosial kognitif Bandura rasa percaya diri sangat penting untuk motivasi anak dalam pembelajaran (Lauster, 2012), ini berhubungan dengan persepsi terhadap efeksi diri yang menentukan cara seseorang berfikir, merasakan, dan berperilaku, kepercayaan diri akan membawa sukses dan sebaliknya, Bandura (Abdullah, 2019). Adapun faktor yang mempengaruhi kepercayaan diri anak adalah faktor internal individu itu sendiri, norma, dan pengalaman, keluarga, tradisi, kebiasaan dalam lingkungan sosial atau kelompok dimana keluarga berasal Loekmono (Tyas, 2018) selain itu, menurut Gürler penerimaan teman sebaya di sekolah merupakan kebutuhan dan berpengaruh besar (Hidayati \& Hidayah, 2020), motivasi (Ardiyana et al., 2019), pengahargaan yang layak terhadap apa yang dilakukan anak (Kim, 2017), kinerja yang ditunjukkan anak memiliki hubungan dengan tingkat kepercayaan diri (Sibert \& Rieg, 2016).

Menurut Lie (Tanjung \& Amelia, 2017) dengan percaya diri anak dapat menyelesaikan tugas sesuai tahapan perkembangan, memiliki keberanian meningkatkan prestasi diri, menjadi pribadi yang sehat dan mandiri. Menurut (Lauster, 2012) kepercayaan diri yang berlebihan bukanlah sifat positif karena akan menimbulkan sifat kurang berhati-hati dan seenaknya sendiri. Upaya yang dilakukan untuk meningkatkan kepercayaan diri anak diantaranya: pembiasaan, menghargai anak, memberikan anak kesempatan untuk tampil dengan mandiri (Suminah et al., 2018). Pada tahap pra-operasional karakteristik kepercayaan diri anak adalah berani mengajukan dan menjawab pertanyaan (Chouinard, 2007), berani tampil di depan teman, guru, orang tua dan lingkungan sosial lainnya, berani menyampaikan keinginan, berani memulai komunikasi dengan orang yang belum dikenal sebelumnya, bangga menunjukkan karya, senang dalam kegiatan bersama, dan tidak mudah terpengaruh (Suminah et al., 2018).

Beberapa strategi dalam meningkatkan kepercayaan diri anak salah satunya adalah dengan jurnal pagi, Menurut Crosby (Dhieni et al., 2017) jurnal pagi (menjurnal) adalah sarana bagi anak untuk menulis dan berbicara tanpa paksaan mengenai kegiatan yang telah mereka lalui. Menjurnal dapat menjadi sebuah kegiatan bagi anak untuk memulai aktivitas dipagi hari dengan cara menulis, menggambar bahkan menceritakan dan berbagi mengenai cerita yang mereka alami. Menurut (Dhieni et al., 2017) Kegiatan jurnal pagi merupakan kegiatan pembuka sebelum anak masuk ke kegiatan pokok pembelajaran. Jurnal pagi (Afandi \& Nurhasanah, 2019) adalah proses pengkondisian anak untuk memasuki rangkaian kegiatankegiatan. menjurnal merupakan proses pembangunan kemampuan kebahasaan yang bersifat expressive. Anak mencoba untuk mengungkapkan gagasan, ide dan pikiran mereka secara langsung melalui tulisan dan lisan menjadi lebih bermakna dan terarah yang mereka sampaikan kepada orang lain. Menurut Cress (Wijaya, 2018) manfaat jurnal pagi mempersiapkan diri anak dalam kegiatan pembelajaran dengan tujuan membentuk suasana berkegiatan yang menyenangkan, nyaman, dan bermakna sehingga akan menuntun gelombang otak untuk aktif dalam kegiatan selanjutnya, sehingga anak akan membantu anak dalam menyerap pembelajaran.

Hasil penelitian (Lailiyah \& Nur, 2020) mengungkapkan melalui jurnal pagi dalam mempersiapkan pembelajaran memberikan dampak positif bagi anak berupa munculnya minat belajar, mampu bertahan hingga selesai kegiatan, dan meningkatkan aspek-aspek perkembangan anak. perbedaannya dengan penelitian yang akan peneliti lakukan adalah penelitian Lailiyah \& Nur hanya menggunakan media gambar sebagai penunjang kegiatan. Penelitian deskriptif yang dilakukan (Dhieni et al., 2017) menunjukan bahwa kemampuan berbicara anak-anak berusia lima hingga enam tahun dalam kegiatan jurnal pagi dapat mempengaruhi lebih dari tujuh kalimat menggunakan SPOK (Subjek, Kata kerja, Perlengkap) dalam struktur kalimat. Selain melihat kemampuan berbicara penelitian ini juga melihat rasa kepercayaan diri anak dan kesabaran dalam menunggu giliran untuk bercerita di depan guru 
dan teman-temannya. Penelitian (Sarnah et al., 2020) mengungkapkan kegiatan jurnal pagi bermanfaat dalam mengembangkan kemampuan menulis permulaan karena dilakukan tanpa paksaan, walau demikian faktor emosi anak yang berubah-ubah dapat menghambat proses penelitian, dengan jurnal pagi anak diajak untuk mengembangkan ide-ide secara bebas dalam bentuk gambar, saat menggambar anak akan mengembangkan kemampuan motoriknya yang akan membantunya dalam mengembangkan kemampuan menulisnya. Perbedaan dengan penelitian yang peneliti lakukan adalah terletak pada media pendukung dan tujuan aspek yang dikembangkan.

Penelitian (Panjaitan et al., 2020) mengungkapkan kepercayaan diri anak dapat dikembangkan dengan bantuan media digital animasi, penelitian ekperimen ini menjelaskan bahwa dengan media pembelajaran digital animasi dapat menarik minat siswa dan membuat siswa lebih cepat mengerti aktif, kreatif, efektif dan menyenangkan. Penelitian yang dilakukan (Fransisca et al., 2020) menyatakan bahwa bermain menggunakan media ular tangga edukasi dapat meningkatkan kepercayaan diri anak, media ular tangga didukung berbagai alat pendukung lainnya seperti pertanyaan pada setiap kotak yang disediakan yang berfungsi untuk melatih anak menjawab pertanyaan tanpa malu-malu, pantang menyerah dalam menyelesaikan tantangan, berani berpendapat, bertanya, berinteraksi, dan ketika anak mendapat kesulitan seperti turun tangga guru memberikan penguatan. Penelitian eksperimen (Ayu Antini et al., 2019) memaparkan bahwa kepercayaan diri anak dapat dikembangkan melalui metode show and tell, dengan metode ini anak terlibat aktif dalam kegiatan pembelajaran dengan mengajak anak untuk bercerita di depan kelas mengenai benda yang dibawanya (merupakan benda pribadi, makanan kesukaan, dan foto/gambar), dengan menggunakan benda konkrit mempermudah anak dalam bercerita dan menarik minat teman dan menunjukkan rasa ingin tahu sehingga memberikan perhatian dan mejadi momen bersinar yang membantu anak untuk lebih percaya diri.

Berdasarkan observasi awal dilakukan peneliti di PAUD Al Istiqlaliyyah pada bulan agustus, bahwa kepercayaan diri anak belum berkembang dengan baik, berdasarkan catatan lapangan dan pengamatan dengan berpedoman pada butir kisi-kisi instrumen yang telah disusun dengan 3 aspek utama kepercayaan diri anak yaitu: padangan positif terhadap diri sendiri, keberanian, dan optimisme, terdapat sembilan dari 12 anak kelompok B masih belum berkembang kepercayaan dirinya. Ditunjukkan pada perilaku (1) Ragu dan malu akan kemampuan yang dimilikinya (2) Kurang dapat berinteraksi dengan baik (3) Memiliki tanggung jawab yang masih rendah dan (4) kurang berkomunikasi dengan teman sebaya. Adapun penyebab kepercayaan anak belum berkembang dengan baik adalah guru hanya berfokus pada perkembangan yang bersifat akademik dan kepercayaan diri anak dipandang bukanlah sesuatuhal yang "urgent" terlihat dari media, materi dan kegiatan yang dilakukan sangat minim untuk mengembangkan kepercayan diri anak. Agar permasalahan tersebut tidak terulang kembali, maka diperlukan solusi yang tepat. Oleh karena itu, peneliti mencoba untuk melakukan kegitan jurnal pagi sebagai solusi dalam memecahkan masalah kepercayaan diri anak di PAUD Al Istiqlaliyyah yang akan peneliti tuangkan dalam bentuk karya ilmiah dengan judul "Peningkatan Kepercayaan Diri Anak Melalui Kegiatan jurnal pagi".

\section{METODOLOGI}

Penelitian ini adalah penelitian tindakan kelas dengan menggunakan mix method dengan prosedur Kemmis dan Mc Taggrart dengan 2 siklus dengan indikator instrumen kegiatan menjurnal sebagai berikut: anak mampu mengajukan pertanyaan, anak mampu menceritakan di depan kelas, anak mampu memilih kegiatan yang akan dilakukan di sekolah, anak mampu mengerjakan tugas, anak dapat berinteraksi dengan orang lain, anak memiliki sikap positif terhadap dirinya, melakukan sesuatu dengan bersungguh-sungguh, anak mampu melakukan kegiatan kegiatan di sekolah tanpa bantuan guru. Penelitian tindakan adalah penelitian yang bersifat partisipatif dan kolaboratif, karena melibatkan orang-orang yang ada dilingkungannya dan hasilnya dapat dinikmati bersama yaitu kepala sekolah dan 
12 anak kelompok B Paud Al-Istiqlaliyyah. Hal ini menjelaskan bahwa penelitian tindakan bertujuan untuk menyelesaikan masalah yang ditemui sehari-hari dalam konteks pembelajaran di kelas (Handini, 2012)

Dalam rancangan penelitian tindakan ini peneliti merencanakan kegiatan penelitiannya berlangsung 8 kali pertemuan selama satu siklus dan akan dilanjutkan dengan siklus kedua sebanyak 8 kali pertemuan jika hasil pada siklus pertama belum mencapai kriteria penilaian atau belum maksimal dengan jumlah sampel 12 anak yang dipilih secara nonprobabilitas dari 27 populasi, penelitian ini dilaksanaklan 17 September 2020 hingga 14 Oktober 2020, bertempat di PAUD Al Istiqlaliyyah Kecamatan Benda Kota Tangerang dan terfokus pada anak Kelompok B yang berjumlah 12 anak dengan 7 perempuan dan 5 laki-laki. Dalam pelaksanaannya karena pada saat siklus kedua pertemuan ke-4 sudah mencapai target yang telah ditentukan yaitu sebesar $75 \%$. Berdasarkan data tersebut, maka peneliti memutuskan untuk tidak lanjut ke siklus selanjutnya.

Tabel 1. Perancangan Waktu Penelitian

\begin{tabular}{|c|c|c|}
\hline No & Kegiatan Penelitian & Waktu Penelitian \\
\hline $\mathbf{1}$ & Observasi awal & Agustus \\
\hline $\mathbf{2}$ & Izin penelitian ke pihak sekolah & Agustus \\
\hline $\mathbf{3}$ & Pra penelitian & September \\
\hline $\mathbf{4}$ & Tindakan siklus I & Oktober \\
\hline $\mathbf{5}$ & Tindakan Siklus II & Oktober \\
\hline
\end{tabular}

Dalam penelitian ini peneliti beserta guru berkolaborasi dalam memperbaiki proses pembelajaran pada anak khususnya pada kepercayaan diri sesuai dengan teknik Miles dan Huberman, analisis data kualitatif terdiri dari mengumpulkan dan merangkum data yang diperoleh (reduksi data) dan disajikan dalam bentuk bagan, grafik atau tabel (display data) agar memudahkan dalam membuat kesimpulan dan menentukan langkah selanjutnya, kemudian melakukan verifikasi data sehingga hasil akhir menunjukkan data peningkatan kepercayaan diri anak dilakukan dengan kegiatan menjurnal pagi dapat memicu anak untuk terlibat aktif dalam belajar karena kegiatan menjurnal ini merupakan kegiatan yang menyenangkan dan menarik bagi siswa. Peneliti dan guru (kolabolator) sepakat bahwa indikator keberhasilan penelitian ini sebesar 75\%, ini merujuk pada ukuran standar yang telah dinyatakan Mills (Mills, 2003). Data yang telah dikumpulkan melalui wawancara semiformal dengan memberikan pertanyaan disesuaikan dengan tema seperti siapa yang mempunyai binatang peliharaan?, bagaimana bunyi suara ayam?, bagaimana bentuk kaki ayam? Apasaja keguanaan air selain untuk mandi?. observasi dengan menggunakan instrumen pemantauan yang terdiri dari perencanan, tindakan dan pengamatan, dan refleksi yang dilakukan selama siklus I dan II, serta dokumentasi dengan menggunakan foto dan video. Untuk memastikan kevalidan data ditingkatkan dengan triangulasi data sebagai upaya menjawab pertanyaan penelitian. Jika data yang diperoleh ternyata saling mendukung, maka data tersebut dapat dikatakan valid dan sebaliknya.

Pada tahap analisis data kualitatif dengan menggunakan statistik deskriptif. Data penelitian yang didapat diangkakan kemudian dipaparkan menggunakan tabel atau grafik untuk menarik kesimpulan secara kuantitatif, analisis statistik memiliki fungsi: menyusun, merangkum, menggambarkan, mendeskripsikan data, dan membantu membuat iduksi atau kesimpulan guna menggeneralisasikan hasil penelitian. Beberapa analisis statistik deskriptif adalah distribusi frekuensi, distribusi persentase, diagram, modus, median, mean dan standar deviasi. Rancangan penelitian dapat dilihat pada tabel 1. 


\section{HASIL DAN PEMBAHASAN}

Pada siklus I dengan sampel 12 anak He, Da, Fe, Zi, Da, Na, Ge, Va, An, Ri, Ve, dan Az saat diberikan tindakan pada siklus ini didapat data dengan skor persentse kepercayaan diri anak He 59.72\%, Da 62.50\%, Fe 59.72\%, Zi 62.50\%, Da 62.50\%, Na 61.11\%, Ge 59.72\%, Va 62.50\%, An 63.89\%, Ri 59.72\%, Ve 68.06\%, dan Az 72.22\%. Ditinjau dari aspek keberanian didapatkan data (He 58.33\%, Da $62.5 \%$, Fe $62.5 \%$, Zi 62.5\%, Dn 62.5\%, Na 62.5\%, Ge 58.33\%, Va $62.5 \%$, An $66.67 \%$, Ri 58.33\%, Ve 70.83\%, dan Az 78.83\%), pada aspek optimis didapatkan data (He 62.5\%, Da 62.5\%, Fe 58.33\%, Zi 62.5\%, Da 62.5\%, Na 62.5\%, Ge 62.5\%, Va 62.5\%, An $62.5 \%$, Ri $58.33 \%$, Ve 70.83\%, dan Az 70.83\%). Aspek pandangan positif pada diri didapatkan data He 58.33\%, Da 62.5\%, Fe 58.33\%, Zi 62.5\%, Da 62.5\%, Na 58.33\%, Ge 58.33\%, Va 62.5\%, An $62.5 \%$, Ri 62.5\%, Ve 66.67\%, dan Az 75\%.

Pada pertemuan pertama dan kedua siklus $1 \mathrm{He}, \mathrm{Fe}, \mathrm{Ge}, \mathrm{Da}, \mathrm{An}, \mathrm{Ri}$, dan Na masih malu maju ke depan kelas, masih ragu menjawab pertanyaan guru, Kemudian pertemuan berikutnya ada beberapa anak yang belum berani tampil (Da, Ge, Va dan An) belum berani tampil namun $\mathrm{Az}$ dan Ve sudah memiliki keberanian mengungkapkan pendapatnya dengan sedikit percaya diri dan masih terbata-bata, anak masih belum dapat mengeluarkan suara dengan lantang dan keras $(\mathrm{Zi})$, pertemuan ke empat ini anak sudah mulai terlihat bersemangat dan antusias seperti Az dan Ve yang memiliki semangat tinggi, dan Ge, Zi, Va dan Ri sudah memiliki keinginan untuk bergaul dengan kelompok dan berinteraksi, walaupun terkadang masih malu dan ragu, namun Da dan Na masih terlihat pemalu ketika menyebutkan fungsi anggota tubuh, akan tetapi ada beberapa yang $\mathrm{Na}$ jawab dengan kurang yakin dan Da sudah berani mencoba menjawab pertanyaan yang diketahuinya. Dan pada pertemuan ke $5 \mathrm{Da}$ mengalami sedikit kemajuan Da sudah terbiasa dengan permainan, menjawab pertanyaan guru dengan suara yang lebih jelas. Ge, He, dan An sudah bermain dengan semangat sesuai dengan arahan guru, berbeda dengan Az dan Ve yang bermain sudah lancar bahkan tanpa arahan guru. Hingga pada pertemuan ke-8 Da dan Ge yang awalnya tidak berani sudah berani bertanya dan berinteraksi kepada guru, He sudah berani bertanya dan menjawab pertanyaan namun kadang masih sedikit ragu-ragu dan membutuhkan bimbingan. Hampir semua anak mengalami peningkatan kepercayaan diri pada suklus ini dibanding tahapan pra-siklus. Pada pertemuan kedelapan pada siklus pertama ini walaupun anak mampu barmain, akan tetapi secara keseluruhan anak belum optimal dan Masih belum sesuai ukuran standar yang telah dinyatakan Mills pada siklu siklus I yaitu 75\% terutama $\mathrm{He}, \mathrm{Fe}, \mathrm{Ge}$ dan $\mathrm{Ri}$ yang mendapat persentase paling rendah dengan persentase $59.72 \%$, dan $\mathrm{Az} 62.50 \%$ dengan persentase yang cukup mendekati standar yang diteapkan namun belum memenuhi standar yang ditetapkan.

Berdasarkan hasil di atas peneliti dan kolaborator melanjutkan ke siklus II. Pada siklus II ini peneliti dan kolaborator akan mengajak anak kegitan menjurnal kembali dengan tantangan dan pertanyaan yang baru, agar menarik keinginan anak untuk mengeluarkan pendapat, serta melatih keberanian anak agar terciptanya percaya diri pada anak, sehingga dengan demikian anak akan akan menjadi lebih baik lagi dari siklus I. Pada siklus kedua didapat data dengan skor persentse kepercayaan diri anak He 80.56\%, Da 81.94\%, Fe 79.17\%, Zi $80.56 \%$, Da $80.56 \%$, Na $81.94 \%$, Ge $80.56 \%$, Va $81.94 \%$, An $80.56 \%$, Ri $80.56 \%$, Ve $88.89 \%$, dan Az 93.06\%. ditinjau dari aspek keberanian He 79.16\%, Da 79.16\%, Fe 79.16\%, Zi 79.16\%, Da 79.16\%, Na 83.33\%, Ge 79.16\%, Va 83.33\%, An 79.16\%, Ri 79.16\%, Ve 87.5\%, dan Az 91.69\%, pada aspek optimis didapatkan data He 79.16\%, Da 83.33\%, Fe 79.16\%, Zi 79.16\%, Da 79.16\%, Na 79.16\%, Ge 79.16\%, Va 79.16\%, An 79.16\%, Ri 79.16\%, Ve 87.5\%, dan Az 91.69\%. Aspek pandangan positif pada diri didapatkan data He 83.33\%, Da 83.33\%, Fe 79.16\%, Zi 83.33\%, Da 83.33\%, Na 83.33\%, Ge 83.33\%, Va 83.33\%, An, Ri 83.33\%, Ve 91.69\%, dan Az 95.83\%.

Pada pertemuan pertama siklus kedua strategi guru dalam menyusun rencana menjurnal pagi pada anak di PAUD Al Istiqlaliyyah mulai menunjukkan perubahan dilihat dari $\mathrm{He}, \mathrm{Da}, \mathrm{Fe}, \mathrm{Zi}, \mathrm{Da}, \mathrm{Na}, \mathrm{Ge}, \mathrm{Va}, \mathrm{An}, \mathrm{Ri}, \mathrm{Ve}$, dan Az sudah mau maju ke depan untuk bermain ulai terlihat semangat dalam mengikuti setiap langkah permainan walau Va masih ragu dan bingung menjawab pertanyaan guru, namun saat guru memberikan bantuan berupa 
intruksi Va mulai mengerti. He, An dan Ri masih malu ketika mendapatkan pertanyaan namun sudah berusaha menjawab dengan sedikit antusias, Zi dan Na antusias bermain namun belum antusias untuk mencari jawaban dari pertanyaan guru.

Pada pertemuan kedua Ve, Az, Va, An, Ri, dan Da sudah dapat bermain berdasarkan inisiatifnya sendiri dalam menentukan maju atau tidaknya ke depan kelas, Fe dan Da masih perlu dibantu guru. Pada pertemuan ketiga siklus kedua ini anak terlihat anak sangat gembira dan ingin maju ke depan kelas, namun terlihat Fe yang mau maju namun masih terlihat malumalu dan sedikit ragu, Da sudah dapat menyelesaikan tugas tanpa dibantu oleh guru, Zi dan He belum terlihat keberanian mengungkapkan pendapatnya dengan percaya diri, terlihat ketika guru meminta anak untuk menceritakan kegiatan di pagi hari hingga ke sekolah dan pengalaman rekreasi. Pada pertemuan keempat semua anak sudah antusias dan semangat mengikuti permainan. Keberanian dan semangat semua anak sudah dapat dilihat ketika semua anak mau maju ke depan kelas tanpa dipanggil oleh ibu guru terlebih dahulu, anakanak pula sudah dapat mengeluarkan pendapat baik kepada guru ataupun teman sekelas, semua anak dapat menyelesaikan tantangan tanpa bantuan guru dan berani menyampaikan pendapatnya di depan kelas tanpa ragu-ragu. Ketika anak-anak bermaian guru masih membacakan kartu perintah, anak sudah dapat bermain dengan semangat dan dapat menjawab semua pertanyaan yang diberikan buru tanpa ragu-ragu, semua anak sudah aktif di dalam kelas, anak-anak pula sudah mengerti tentang rekreasi dan bagaimana tata tertib rekreasi.

Peneliti dan kolaborator mengamati proses kegiatan untuk melihat apakah tindakan yang diberikan telah sesuai dengan apa yang rencanakan. Percaya diri anak lebih meningkat dibandingkan sebelumnya. Pengamatan yang dilakukan dengan menggunakan instrumen pemantau tindakan. Peneliti dan kolaborator melakukan analisis proses sejauh mana aktivitas peneliti dalam melakukan tindakan dan aktivitas anak dalam proses pembelajaran yang telah sesuai dengan perencanaan tindakan yang telah disusun. Berdasarkan dari data observasi, aktivitas guru dan aktivitas anak telah berjalan sesuai dengan apa yang telah direncanakan. Disertai dengan selalu memberikan pemahaman kepada anak tentang yakin pada diri sendiri, berani mengeluarkan pendapat, bersemangat serta aktif di dalam kelas. Perbandingan persentase pra-siklus, siklus I dan siklus II dapat dilihat pada tabel 1.

Tabel 2. Data Percaya Diri Anak Kelompok B Di PAUD Al Istiqlaliyyah Pra Siklus - Siklus I Siklus II

\begin{tabular}{|c|c|c|c|c|c|c|c|}
\hline No. & Nama & $\begin{array}{c}\text { Skor } \\
\text { Pra } \\
\text { Siklus }\end{array}$ & \% & $\begin{array}{c}\text { Skor } \\
\text { Siklus } \\
\text { I }\end{array}$ & \% & $\begin{array}{c}\text { Skor } \\
\text { Siklus } \\
\text { II }\end{array}$ & \% \\
\hline 1. & $\mathrm{He}$ & 31 & 43.06 & 43 & 59.72 & 58 & 80.56 \\
\hline 2. & $\mathrm{Da}$ & 32 & 44.44 & 45 & 62.50 & 59 & 81.94 \\
\hline 3. & $\mathrm{Fe}$ & 29 & 40.28 & 43 & 59.72 & 57 & 79.17 \\
\hline 4. & $\mathrm{Zi}$ & 32 & 44.44 & 45 & 62.50 & 58 & 80.56 \\
\hline 5. & $\mathrm{Da}$ & 34 & 47.22 & 45 & 62.50 & 58 & 80.56 \\
\hline 6. & $\mathrm{Na}$ & 33 & 45.83 & 44 & 61.11 & 59 & 81.94 \\
\hline 7. & $\mathrm{Ge}$ & 29 & 40.28 & 43 & 59.72 & 58 & 80.56 \\
\hline 8. & $\mathrm{Va}$ & 34 & 47.22 & 45 & 62.50 & 59 & 81.94 \\
\hline 9. & $\mathrm{An}$ & 32 & 44.44 & 46 & 63.89 & 58 & 80.56 \\
\hline 10. & $\mathrm{Ri}$ & 31 & 43.06 & 43 & 59.72 & 58 & 80.56 \\
\hline 11. & $\mathrm{Ve}$ & 38 & 52.78 & 49 & 68.06 & 64 & 88.89 \\
\hline 12. & $\mathrm{Az}$ & 45 & 62.50 & 52 & 72.22 & 67 & 93.06 \\
\hline \multicolumn{2}{|l|}{ Rata-rata } & & $\mathbf{4 6 . 3 0 \%}$ & & $\mathbf{6 2 . 8 5} \mathbf{0}$ & & $\mathbf{8 2 . 5 2 \%}$ \\
\hline
\end{tabular}

Berdasarkan Tabel 2 menunjukkan peningkatan rata-rata skor percaya diri anak melalui kegiatan menjurnal pada pra siklus, siklus I dan II cukup signifikan dengan 
peningkatan dari pra-siklus $46.30 \%$, siklus I $62.85 \%$ dan siklus II $82.52 \%$. Dapat dideskripsi bahwa persentase rata-rata keberhasilan pada siklus II adalah $82.52 \%$. Hal ini berarti sudah mencapai target yang telah ditentukan yaitu sebesar $75 \%$ yang merujuk pada pendapat Mills yang menyatakan bahwa penelitian yang memiliki tingkat keberhasilan penelitian apabila mencapai 71\% dari jumlah keseluruhan siswa (koresponden) (Mills, 2003:101). Berdasarkan data tersebut yang didapat pada pertemuan ke4 siklus II, maka peneliti memutuskan untuk tidak lanjut ke siklus selanjutnya karena sudah mencapai target persentase percaya diri yang meningkat maka persentase kenaikan dinyatakan signifikan. Dengan demikian hipotesis tindakan yang menyatakan bahwa melalui kegiatan jurnal pagi dapat meningkatkan percaya diri anak kelompok B PAUD Al Istiqlaliyyah diterima. Peningkatan percaya diri anak juga dapat dilihat secara keseluruhan yang dialami anak dari setiap masing-masing aspek perkembangan positif pada diri sendiri, keberanian dan optimis. Perolehan presentase setiap anak pada setiap siklus berbeda-beda. Hal ini dapat dipengaruhi oleh faktor internal dan eksternal.

Dalam pelaksanaan penelitian kegiatan jurnal pagi dalam meningkatkan rasa percaya diri anak kelompok B di Paud Al-Istiqlaliyyah adalah kegiatan yang dilakukan sebagai kegiatan pembuka atau memulai aktivitas dipagi dengan cara mengungkapkan gagasan, ide dan pikiran secara langsung dengan cara menulis, menggambar dan bercerita tentang aktivitas yang telah mereka lalui, dalam prosesnya dilakukan dengan cara bermain karena dengan bermain anak dapat menambah pengetahuan, keterampilan, dan pengalamanpengalaman melalui interaksi nyata sehingga mendorong tumbuhnya rasa percaya diri. Jurnal pagi dibantu dengan media pendukung berupa kartu perintah dan pertanyaan-pertanyaan yang dirancang berdasarkan tema untuk menarik minat anak dan melatih anak mengenal kosa kata baru sehingga saat anak tampil tidak malu-malu karena memiliki perbendaharaan kata yang dikuasai, selain itu kemampuan anak dalam mendeskripsikan kartu perintah dan menjawaban pertanyaan akan membuat anak yang awalnya tidak berani menjadi berani mengungkapkan pendapat, berani bertanya dan memberikan pertanyaan, berani berinteraksi dengan teman, pantang menyerah, semangat dalam mengerjakan tugas, dan berani maju ke depan, ketika menemukan kendala dengasn penguatan yang diberikan guru anak termotivasi untuk semangat dan pantang menyerah, dengan kegiatan ini diharapkan anak terbiasa yakin pada diri sendiri, melatih keberanian anak dan optimis dengan diri sendiri saat melakukan sesuatu.

Temuan dalam proses tindakan saat melakukan kegiatan menjurnal dalam meningkatkan percaya diri anak, diantaranya kegiatan jurnal pagi dapat membuat anak memiliki pandangan positif terhadap diri sendiri, mampu berinteraksi dengan teman lain serta anak sudah mampu mengerjakan tugas, Kegiatan menjurnal dapat merangsang anak meluapkan emosi anak dengan baik, sehingga berdampak kepada percaya diri anak. Hal ini sejalan dengan pendapat (Buli et al, 2020) kegiatan menjurnal merupakan kegiatan yang mampu merangsang anak untuk belajar memecahkan dan menyelesaikan suatu masalah sederhana tanpa dapat disadari oleh anak itu sendiri. Temuan selanjutnya saat anak melakukan kegiatan menjurnal, keberanian anak untuk maju ke depan kelas, dan berani mengungkapkan pendapat meningkat, sejalan dengan pendapat (Hsu et al., 2019). Di dalam konteks permainan anak di tuntut untuk dapat menggunakan berbagai keterampilan untuk mengatasi berbagai pemecahan masalah, permainan edukatif menciptakan situasi bermain (belajar) yang menyenangkan bagi anak, menumbuhkan rasa percaya diri dan membentuk citra diri anak yang positif. Kegiatan menjurnal anak memiliki rasa optimis, anak pantang menyerah dalam mengerjakan tugas dan anak terus berusaha untuk mendapatkan apa yang diinginkan, menurut (Hildayani, 2005) ketertarikan anak terhadap kegiatan menjurnal, membuat anak-anak sangat antusias mengikutinya. Dengan bantuan kartu perintah yang prosesnya dilakukan dengan bermain, permainan yang menggunakan aturan ini sangat menstimulasi anak untuk meningkatkan rasa percaya diri, dalam penelitian ini ditemukan anak-anak bersemangat dalam melakukan kegiatan, dan pantang menyerah. Ini sejalan 
dengan penelitian (Lailiyah \& Nur, 2020) yang menyatakan bahwa dengan jurnal pagi anak mampu mengikuti kegiatan sampai pembelajaran usia (minat bertahan dalam belajar) dan menambah minat anak dalam belajar.

\section{SIMPULAN}

Kegiatan jurnal pagi dapat meningkatkan percaya diri pada anak kelompok B Paud Al Istiqlaliyyah, hal ini dapat dibuktikan dengan hasil penelitian yang meningkat setiap siklusnya, serta terlihat dari persentase peningkatan percaya diri anak dari pra tindakan, siklus I dan siklus II. Terjadi peningkatan yang signifikan setelah diberikan tindakan berupa kegiatan menjurnal yang divariasikan dengan kartu perintah dan dirancang berdasarkan tema, dari penelitian yang telah dilakukan bahwa dengan penerapan kegiatan menjurnal ini percaya diri anak kelompok B Paud Al Istiqlaliyyah meningkat dari sebelumnya. Penelitian ini diharapkan dapat bermanfaat bagi pengembangan keilmuan terkait pengembangan kepercayaan diri anak, berguna secara praktis oleh guru dan orangtua dalam memberi alternatif kegiatan dalam meningkatkan kepercayaan diri anak.

\section{UCAPAN TERIMA KASIH}

Terimakasih peneliti ucapkan kepada Allah SWT atas limpahan rahmat-Nya dan petunjuknya sehingga peneliti dapat melaksanakan penelitian dan menyelesaikan karya ilmiah ini. Dosen pembimbing yang telah memberikan saran dan masukan selama penyusunan karya ilmiah, kedua orangtua peneliti yang doa dan dukungannya yang selalu mengalir, pihak sekolah khusunya kepala sekolah dan 12 anak Paud Al-Istiqlaliyyah, Kecamatan Benda, Kota Tangerang, Banten atas kerjasama selama peneliti melakukan penelitian.

\section{DAFTAR PUSTAKA}

Abdullah, S. M. (2019). Social Cognitive Theory: A Bandura Thought Review Published In 1982-2012. Psikodimensia, 18(1), 85. Https://Doi.Org/10.24167/Psidim.V18i1.1708

Afandi, Richard D S, \& Nurhasanah, N. (2019). Rahasia Mengenal Anak Melalui Gambar. Eternity Publishing.

Ardiyana, R. D., Akbar, Z., \& Karnadi, K. (2019). Pengaruh Keterlibatan Orang Tua Dan Motivasi Intrinsik Dengan Kepercayaan Diri Anak Usia Dini. Jurnal Obsesi : Jurnal Pendidikan Anak Usia Dini, 3(2), 494. Https://Doi.Org/10.31004/Obsesi.V3i2.253

Ayu Antini, N. K., Magta, M., \& Ujianti, P. R. (2019). Pengaruh Metode Show And Tell Terhadap Kepercayaan Diri Anak Kelompok A Taman Kanak-Kanak. Jurnal Pendidikan Anak Usia Dini Undiksha, 7(2), 143. Https:/ / Doi.Org/10.23887/Paud.V7i2.18884

Chouinard. (2007). Children's Question: A Mechanism For Cognitive Development. Monographs of The Society For Researh In Child Development, 72(1), Vii-Ix. Https://Doi.Org/10.1111/J.1540-5834.2007.00412.X

Dhieni, N., Hapidin, \& Ningtias, A. A. (2017). The Speaking Ability Of Five To Six-Year-Old Children In Morning Journal Activity. International Journal Of Education And Research, 5(5), 223-230 ISSN: 2411-5681.

Fransisca, R., Wulan, S., \& Supena, A. (2020). Meningkatkan Percaya Diri Anak Dengan Permainan Ular Tangga Edukasi. Jurnal Obsesi : Jurnal Pendidikan Anak Usia Dini, 4(2), 630. Https://Doi.Org/10.31004/Obsesi.V4i2.405

Handini, M. C. (2012). Metodologi Penelitian Untuk Pemula. G.P. UTAMA.

Hidayati, R., \& Hidayah, N. (2020). The Differences Of Students ' Self-Confidence Level In Full Day Class And Regular Class Of Elementary School. 9(4), 649-655. Https://Doi.Org/10.23887/Jpi-Undiksha.V9i4.22356

Hildayani, R. (2005). Psikologi Perkembangan Anak. Universitas Terbuka.

Hsu, C. Y., Chiou, G. L., \& Tsai, M. J. (2019). Visual Behavior And Self-Efficacy Of Game Playing: An Eye Movement Analysis. Interactive Learning Environments, 27(7), 942-952. 
Https:/ / Doi.Org/10.1080/10494820.2018.1504309

Kim, K. J. S.-J. B. B. (2017). Opening A Window To Foster Children's Self-Confidence Through Creative Art Activities. Dimensions Of Early Childhood, 45(2), 4-12. ISSN-1068-6177

Lailiyah, U., \& Nur, F. N. (2020). Kesiapan Belajar Anak Melalui Jurnal Pagi Di TK ABA

Giwangan Yogyakarta. Journal On Early Childhood Education Research (JOECHER), 1(2), 82-89. Https://Doi.Org/10.37985/Joecher.V1i2.9

Lauster, P. (2012). Tes Kepribadian (Terjemahan Oleh DH Gulo). Bumi Aksara.

Mills, G. E. (2003). Action Research: A Guide For The Teacher Researcher. ERIC.

Nurmaniah, \& Damayanti, I. (2018). Upaya Meningkatkan Kepercayaan Diri Anak Usia 5-6 Tahun Melalui Metode Demonstrasi Di PAUD Binika Desa Sukaramai - Langkat. Jurnal Diversita, 4(1), 52-57. Https:/ /Org/: Https:/ / Doi.Org/10.31289/Diversita.V5i2

Panjaitan, N. Q., Yetti, E., \& Nurani, Y. (2020). Pengaruh Media Pembelajaran Digital Animasi Dan Kepercayaan Diri Terhadap Hasil Belajar Pendidikan Agama Islam Anak. Jurnal Obsesi : Jurnal Pendidikan Anak Usia Dini, 4(2), 588. Https://Doi.Org/10.31004/Obsesi.V4i2.404

Sarnah, S., Fadlullah, \& Sayekti, T. (2020). Pelaksanaan Kegiatan Jurnal Pagi Dalam Mengembangkan Kemampuan Menulis Permulaan Pada Anak Usia 5-6 Tahun. Prosiding Seminar Dan Diskusi Nasional Pendidikan Dasar 2020 'Transformasi Pendidikan Menyongsong SDM Di Era Society 5.0', 1-15. E-ISSN 2549-5801

Sibert, S. M. ., \& Rieg, S. (2016). Early Childhood Special Education Pre-Service Teachers: Perceived Self-Confidence In Traditional And Professional Development School Field Placements. National Teacher Education Journal, 9(2), 47-56. ISSN 2157-0590

Suminah, E., Nugraha, A., Yusuf, F., Puspita, W. A., \& Soendjojo, R. P. (2018). Kerangka Dasar Dan Struktur Kurikulum 2013 PAUD (Issue 021).

Syam, A., \& Amri. (2017). Pengaruh Kepercayaan Diri ( Self Confidence) Berbasis Kaderisasi Imm Terhadap Prestasi Belajar Mahasiswa ( Studi Kasus Di Program Studi Pendidikan Biologi Fakultas Keguruan Dan Ilmu Pendidikan Universitas Muhammadiyah Parepare ). Jurnal Biotek, 5(1), 87-102. https://doi.org/10.24252/jb.v5i1.3448

Tanjung, Z., \& Amelia, S. (2017). Menumbuhkan Kepercayaan Diri Siswa. JRTI (Jurnal Riset Tindakan Indonesia), 2(2), 2-6. Https:/ / Doi.Org/10.29210/3003205000

Tyas, A. K. (2018). Pengaruh Bimbingan Kelompok Dengan Teknik Sosiodrama Terhadap Percaya Diri Siwa. 02(02), 4. Https:// ISSN : 2599-073X

Wijaya, P. K. (2018). Peningkatan Kemampuan Keaksaraan Melalui Kegiatan Menjurnal. Al Marhalah: Jurnal Pendidikan Islam., Volume. 2,(mei), 13-30. https:// doi.org/10.38153/alm.v2i1.13 